\title{
Devlet-i Aliyye Osmanlı İmparatorluğu Üzerine Araştırmalar-IV (Ayanlar, Tanzimat, Meşrutiyet) ${ }^{1}$
}

\author{
Halil İnalcık, Türkiye İş Bankası Kültür Yayınları, İstanbul, 2.Basım, Aralık 2016, 572 Sayfa. \\ Gürdal Çetinkaya ${ }^{2}$ \\ Ankara University, Phd Student, Department of History, Ankara, Turkey \\ Received- Accepted: 07.06. 2019-03.07.2019 \\ Book Review
}

Türk Tarihinin son duayenlerinden biri olan Halil İnalckk’’n dört kitap halinde kaleme aldığı Devlet-i Aliyye serisinin dördüncü kitabı olan ' Osmanlı İmparatorluğu Üzerine Araştırmalar-IV (Ayanlar, Tanzimat, Meşrutiyet)" isimli eserle yazar Osmanlı'nın 1600'lü ylllarından başlayarak Cumhuriyet Dönemine kadar olan süreçteki meydana gelen olayları çarpıcı ve bir o kadar da sürükleyici bir şekilde ele almaktadır.

Diğer üç kitap ve incelemesini yapacağım dördüncü kitapta Osmanlı Devleti hakkında bildiklerimizden daha çok bugüne kadar belki de hiç duymadığımız birçok bilgiyi öğrenme firsatına sahip oluyoruz. Öyle ki bu kitapları okumaya başladığınız zaman gerçekten her sayfasında Osmanlı Tarihi adına yeni ve orijinal bir bilgi ile karşılaşmamız mümkündür. Eser bu yönüyle alanında yazılmış birçok Osmanlı Tarihi kitabından daha sağlam ve güvenilir bilgileri okuyucuları ile paylaşmaktadır.

İncelemesini yapacağım kitap Türkiye İş Bankası Kültür Yayınlan tarafindan yayınlanmıştır. Eser toplamda 557 sayfadan meydana gelmiştir. Eser A'dan F'ye kadar isimlendirilerek verilmiş 6 ana bölümden meydana gelmektedir. Ayrıca eser'in 'Ekler" bölümünde de "Osmanlı Tarihi Kronolojisi” ayrnntılı bir şekilde verilmiştir. Yine bu bölümde gözümüze çarpan ' 'Berlin Antlaşmasının Osmanlıca Orïinal Metni”, 'Mondros Silah Bırakışımı Sözleşmesi Metni” ve 'Misak-ı Milli” metnidir. Ayrıca eserin sonuna konulan 'Dizin” bölümü de birçok eserde çok fazla önemsenmemesine rağmen özellikle tarih alanında yazılan kitaplar açısından büyük önem taşımaktadır.

Yazar eserin ana bölümlerine geçmeden önce kısa bir "Giriş" bölümüne yer vermiştir. "Giriş" bölümünde yazar "Osmanl Devlet ve Toplumunda Yeni Dönem” den, 'Tanzimat" ve "Meşrutiyet" ten bahsetmiştir. Bu bölümde özellikle belirtmek isterim ki yazar'nn eserini 1600’lü ylllardan başlatarak kaleme almasıyla giriş bölümünde ele aldığı bu konular bir bütünlük göstermemektedir. Zaten yazar eserin ilerleyen bölümlerinde giriş bölümünde ele aldığı konulara oldukça ayrıntılı bir şekilde yer vermiş̧ir. Bu durumda yazar böyle bir giriş bölümüne yer vermektense giriş bölümünde ele aldığı konulara eserin ilerleyen bölümlerinde de yer verebilirdi. Giriş bölümü nün Osmanlı Tarihini merak ederek okumaya başlayanlar açısından konu bütünlüğünü bozucu bir etki yapması muhtemeldir.

Eserin ilk bölümünün başlığını “'Askeri ve Mali Dönüşüm (1600-1700)” oluşturmaktadır. Bu bölümde

\footnotetext{
${ }^{1}$ This article is analyzed by two reviewers and it is screened for the resembalance rate by the editor. (Bu makale iki hakem tarafindan incelenmiş ve editör tarafindan benzerlik oranı taramasından geçirilmiştir)

2 gurdal_45@hotmail.com, ORCID:0000-0002-2651-1779
} 
Devlet-i Aliyye Osmanlı İmparatorluğu Üzerine Araștırmalar-IV (Ayanlar, Tanzimat, Meșrutiyet)/ Gürdal ÇETINKAYA

ilk olarak 17. yüzyıldaki idari ve mali sistemdeki dönüşüm üzerinde durulmuştur. Hemen ardından ise askeri teşkilatta meydana gelen dönüşüm ele alınmıştır. Özellikle bu bölümdeki 'Sekban-Yeniçeri Çekişmesi” isimli başıı ve sonrasında anlatılanlar Osmanlı Askeri Teşkilatı'na çok daha farklı bir perspektiften bakmamızı sağlayacaktır. Özellikle Sekbanlık konusunda "Yeğen Osman Paşa" nın giriştiği birçok faaliyet o dönemi anlamamız açısından oldukça önemlidir. Yine bu bölümün devam eden bir diğer konusu ise 'Mali Sistemde Yaşanan Dönüşüm ve Sonuçları” dır. Bu konu başlığı altında ise alınmaya başlanılan yeni vergiler ve vergi toplama yöntemlerinden bahsedilmektedir.

Eserin ikinci bölümünde 'Osmanl Yönetiminde Ayanlar Dönemi” ele alınmaktadır. Yazar ayanlar konusunu eserde oldukça geniş bir şekilde ele almıştır. Yazar, ayanlar konusunu 1600'lü yıllardan başlatarak III. Selim dönemine kadar getirmiştir. Yine yazar bu bölümde döneme damgasını vurmuş önemli bazı ayan ailelerinden de söz etmiştir. Bu bölümde ayanlar için dikkatimizi çeken bir diğer noktada 1784 yilında yapılan reformlar sonucunda kazalarda ayanların seçilmesi hususunda yapılan değişikliklerdir. Bu bölümün belki de en önemli ve dikkate değer konu başlığ ise 'Sened-i İttifak" tır. Yazar bu başlık altında Sened-i İttifak'1 oldukça ayrıntılı bir şekilde ele almıştır. İk olarak Sened-i İttifak'ın esas noktalarına değindikten sonra Sened-i İttifak'ın kapsamlı bir şekilde tahliline yer vererek değerlendirmelerde bulunmuştur.

Eserin üçüncü bölümünü '’llk Batlllaşma Girişimi (1700-1730)” isimli başlık oluşturmaktadır. Yazar Osmanlı Tarihi'nde araştırma yapan birçok tarihçi ve araştırmacı tarafindan bilinen 'Dimitri Kantemir" i bu bölümde ele almaktadır. Yazar Kantemir hakkında şu bilgileri aktarmıştır:

'Osmanlı sarayında Doğu kültürünün en ince temsilcileriyle yakandan temasa geçmiş olan Beyzade Kantemir, Doğu ve Batı kültürlerinin buluşmasında rol oynamıştır. Kantemir, 15 yaşındayken, 1688'de İstanbul'a gelmis ve ömrünün 22 yllın Osmanl payitahtında Doğu'nun, Batı'nin fikir hayatına ortak bir hayat geçirmiştir. Kantemir'in Ortaköy'deki evinde bestelediği parçalar Türk musikisi tarihinde tartışlmaz bir yer edinmiştir. Kısacası Dimitri Kantemir, Osmanlı başkentindeki yeni kültürel yönelişe yön verenlerden biridir, aynı zamanda kendisi Istanbul'un kültür ve fikir hayatınin bir ürünüdür."

Ayrıca Kantemir'in Avrupa kültürü ile ilgilide çalışmalanı mevcuttur. Yine kendisinin Osmanlı İmparatorluğu hakkındaki çalışması da Avrupa'da standart bir eser olarak kabul edilmiştir. Yazar bu bölümün devamında Osmanlı Devleti’nin Avrupa ile olan kültürlerarası etkileşiminden bahsetmektedir. Eserde Osmanlı Devleti'nin kuruluşundan 19. Yüzyıla kadar geçen süre içerisinde Avrupa'nın kültürel anlamda Osmanlı Devleti'ni nasıl etkilediğini çarpıı bir şekilde ele alınmaktadır. Aynı kısımda kültürel alanda ele alınan diğer bir konu ise 'Lale Devri” dir. Lale Devri'ni ayrnntılı bir şekilde inceleyen yazar bu bölümü söz konusu devrin sona ermesine neden olan Patrona Halil İsyan'1 ile tamamlamıştır.

Yazar eserin dördüncü bölümünde 'Tanzimat (1839-1876)ve İk Meşrutiyet: Kanun-i Esasi”den bahsetmiştir. Yazar Tanzimat Fermanı'nın tahlilinden sonra Ferman'ın içeriğinden ve Fermanı hazırlayan grup'tan söz etmiştir. Yine Ferman'ın Osmanlı Devleti’ne getirdiği modern prensiplerin de üzerinde durulmuştur. Yazar 
Tanzimat Fermanı ile ilgili olarak görüşlerini şu cümlelerle ortaya koymaktadır:

'Tanzimat tan gaye, devletin kuvvetlenmesi, memleketin kalknmast ve huzurun yerleşmesidir.

Müslim ve gayrimüslim bütün tebaann ayn haklardan istifade etmesi prensibi, uslahattan beklenen pratikgayeyi ortaya koymaktayd."

Yazar eserin devam eden bu bölümünün sonunda ise Tanzimat'ın uygulanması ve Osmanlı toplumundan fermana yönelik oluşan tepkilerden bahsetmiş̧tir. Yazar Tanzimat'n Rumeli'de ki etkilerini de değinmiştir. 1841 tarihinde Niş ve 1850 Vidin İsyanların ele alan yazar Tanzimat'ın reaya'ya olan etkilerini ortaya koyduktan sonra 1848 Avrupa ihtilallerinin Osmanlı Devleti'ne tesiri hakkında bilgi vermiş̧ir. Bu bölümde son olarak ise yazar 1876 tarihli Osmanlı Kanun-i Esasi'sini ele almıştır.

Eserin beşinci bölümünde 'Türkiye ve Avrupa" isimli başlı adı altında Osmanlı'nı Avrupa ile ilişkilerine değinilmiş̧ir. Illk olarak bu ilişkilerin ekonomik boyutu olan kapitülasyonlar ve coğrafi keşifler konusu ele alınmıştır. Ardından Avrupa ile ilişkilerin siyasi, dini ve kültürel boyutundan bahsedilmiştir. Yine bu bölümde 1500'lü ylllardan itibaren başlayarak 1683 Viyana Bozgunu'na geçen süreç içerisindeki Haçılların, Türklere karşı yürüttükleri projelerden söz edilmiş̧ir. 1768-1792 Osmanlı-Rus ilişkileri ele alındıktan sonra 1877-78 Osmanl-Rus Savaşı ve hemen ardından imzalanan Ayastefanos ve Berlin antlaşmalarından söz edilmiştir. Bu bölümün sonunda da Osmanlı Devleti'nin 1878 Berlin Antlaşması'ndan sonraki süreçte Büyük Devletlerle olan ilişkilerine değinilmiş̧ir.

Eserin son bölümünü '’lkinci Meşrutiyet: Modern Türkiye'nin Doğuş̧u” isimli başlk oluşturmaktadır. Bu bölümde yazar İkinci Meşrutiyet'in ilanı sonucunda Osmanlı'nın iç siyasetine ve Avrupalı büyük devletlerle olan iliş̧ilerine değinmiştir. İkinci Meşrutiyet döneminin getirmiş olduğu fikir akımlarından olan 'Hilafet Hareketi, Şeriatçllk, Osmanlllk, Batıcllk, Turancı Türkçülük" akımlarını ele alarak Turancı Türkçülüğün temsilcilerinden olan İsmail Gaspırah ve Yusuf Akçura ile yine Türkçülüğün en önemli temsilcisi olan Ziya Gökalp'in düşüncelerinden de bahsetmiş̧ir. Yazar tüm bunlardan söz ettikten sonra Anadolu'da Milli Türk Devleti'nin doğuşu konusuna geçmiştir. Yine bu konuda yazar saltanatın ve hilafetin kaldırılması konularnna değinmiştir. Yazar burada hilafetin kaldırlmasından 'Büyük Devrim” olarak bahsetmişstir. Bölümün sonunda ise Atatürk'ün kurmuş olduğu Modern Türkiye'den bahsedilerek modernleşme problemini ele almıştrı.

Eserin sonunda ise yazar oldukça zengin bir "Ekler" bölümüne yer vererek Osmanlı tarihi alanında araştrrma yapan veya bu döneme meraklı olan kişiler için geniş bir içerik sunmuştur. Görüldüğü üzere eser Osmanlı'nın sadece son dönemlerini ele almakla kalmamış Türkiye Cumhuriyeti Devleti'nin kuruluş yolundaki aşamalarına da yer vermiştir. Osmanlı tarihini anlatan bir eser olması dolayısıyla birçok kişi sıkıcı ve anlaşılmaz bir eserle karşı karşıya kalacağını düşünmüş olabilir. Fakat incelemesini yaptığım eser ilk başta oldukça hacimli olmasına rağmen yazarın kullanmış olduğu anlaşlır dil eseri keyif alarak takip etmemi sağlamıştır. 